\title{
Radical-scavenging and Pro-/anti-inflammatory Activity of Tetracycline and Related Phenolic Compounds With or Without Visible Light Irradiation
}

\author{
YUKIO MURAKAMI, AKIFUMI KAWATA, SEIJI SUZUKI and SEIICHIRO FUJISAWA
}

\author{
Division of Oral Diagnosis and General Dentistry, Department of Diagnostic and Therapeutic Sciences, \\ Meikai University School of Dentistry, Sakado, Japan
}

\begin{abstract}
Background/Aim: Microbial tetracycline (TC) pastes have been employed to treat oral bacterial infection. In the present study, we investigated the kinetic radicalscavenging and pro-/anti-inflammatory activity of TC with or without visible light irradiation (VLI). Materials and Methods: The radical-scavenging activity of TC and minocycline $(M C)$ was determined by differential scanning calorimetry (DSC). The stoichiometric factor $(n)$ and the rate constant of inhibition and propagation $\left(k_{i n h} / k_{p}\right)$ were determined. The levels of cyclooxygenase-2 (Cox2), tumor necrosis factor- $\alpha$ (Tnf $\alpha$ ) or nitric oxide synthase 2 (Nos2) mRNA in RAW264.7 cells stimulated with lipopolysaccharide (LPS) were investigated using real-time reverse transcriptasepolymerase chain reaction. Results: The $n$ and $k_{i n h} / k_{p}$ values for $1 \mathrm{mM}$ TC in 2,2'-azobisisobutyronitrile and benzoyl peroxide systems were 0.1-0.2 and 119-250, respectively, whereas the corresponding values for quercetin $(Q U)$ and resveratrol (RE) were $2-4$ and $7-15$, respectively. In RAW264.7 cells stimulated with LPS, Cox2 and Tnfa mRNA were over-expressed in the presence of TC. MC downregulated only the expression of Cox 2 by about $50 \%$ in LPSstimulated cells. The anti-inflammatory activity determined on the basis of Cox2 inhibition declined in the order $Q U>R E>M C>T C$. Upon application of VLI, only TC downregulated the expression of LPS-stimulated Cox 2 and Tnfa mRNA. After exposure to VLI, TC, but not MC, markedly up-
\end{abstract}

This article is freely accessible online.

Correspondence to: Dr. Yukio Murakami, Division of Oral Diagnosis and General Dentistry, Department of Diagnostic and Therapeutic Sciences, Meikai University School of Dentistry, 1-1 Keyakidai, Sakado City, Saitama 350-0283, Japan. Tel: +81 492855511, Fax: +81 492876657, e-mail: ymura@dent.meikai.ac.jp

Key Words: Radical-scavenging activity, tetracyclines, LPS, Cox2, Nos2, Tnf $\alpha$, Ho-1, visible light, RAW264.7 cell. regulated hemoxygenase-1 (Ho-1) expression. Conclusion: TC is a chain-breaking antioxidant with a large $k_{\text {inh }}$. Upon activation by VLI, TC may undergo degradation and its degradation products affect pleiotropic mediators such as Cox2, Tnfa and Ho-1. TC may be useful as a local photodynamic therapy for periodontal diseases.

Tetracyclines such as tetracycline (TC) and minocycline (MC) are highly effective against gram-positive and gramnegative bacteria. These antibiotics are complex molecules with unique chemically connected ring systems (designated A through D) with multiple ionizable functional groups (Figure 1). Because tetracyclines possess multiple $\mathrm{O}-$ and $\mathrm{N}$ functions, their strong tendency to form complexes with metals such as $\mathrm{Cu}^{2+}, \mathrm{Fe}^{2+}$ and $\mathrm{Zn}^{2+}$ is well documented (1, 2). Also, previous studies have shown that TC may undergo degradation depending on $\mathrm{pH}$, redox status and light conditions (3, 4). Many reports have indicated that tetracyclines have anti-protease effects such as matrixmetalloprotease (MMP) activity, anti-apoptotic effects, reactive oxygen species (ROS) scavenging activity and antiinflammatory activity $(1,5-7)$. Tetracyclines have been used for the treatment of generalized and localized aggressive periodontitis that is refractory to treatment (8). However, with the emergence of resistant species of bacteria, tetracyclines have been replaced by more effective combinations of antibiotics (9). Additionally, tetracyclines have adverse effects such as transient retardation of bone growth, photosensitivity, permanent discoloration of developing teeth and teratogenesis, as well as hepatic and renal toxicity in susceptible individuals (10). They also have beneficial actions, including ROS scavenging and antiinflammatory function (11).

The RAW264.7 murine cell line has been an important tool for in vitro studies of inflammation involving activation of the receptor for nuclear factor-kB (NF-kB) ligand (RANKL)-mediated periodontal bone resorption in periodontitis (12). Also, we have previously investigated the 


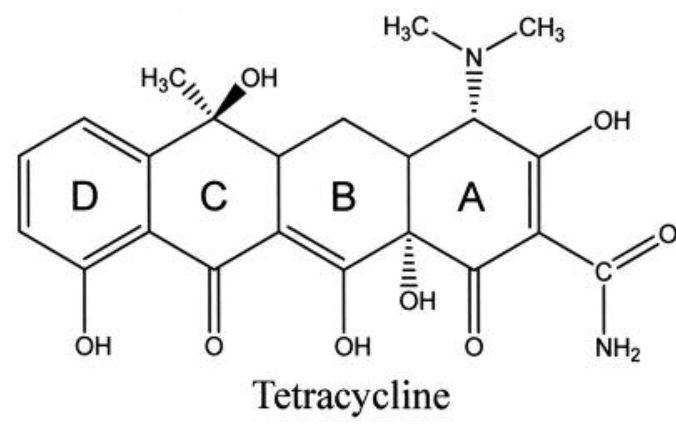

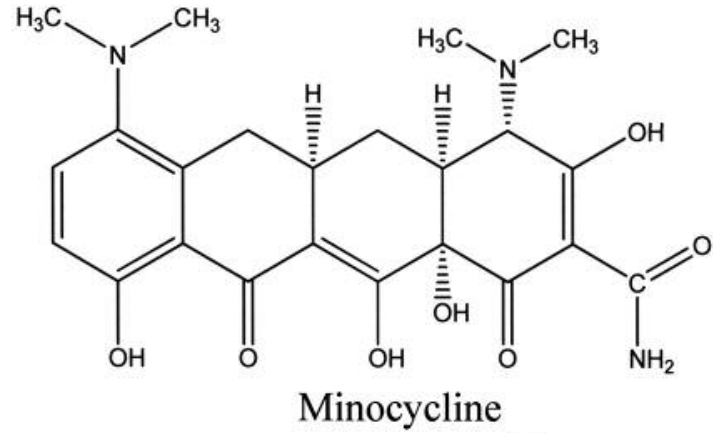

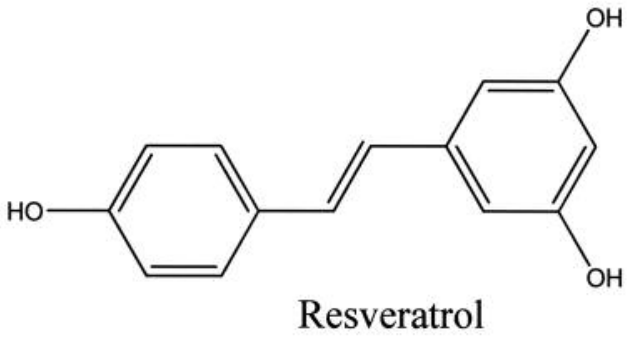

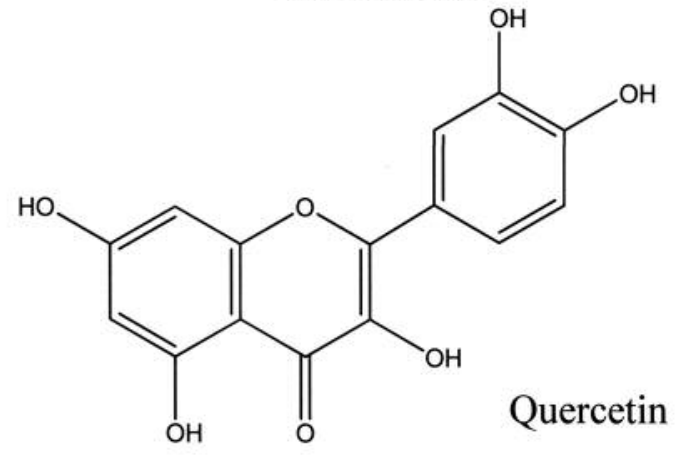

Figure 1. Chemical structures of tetracycline, minocycline, resveratrol and quercetin.

cytotoxicity and potential anti-inflammatory activity of various phytophenols on RAW264.7 cells stimulated with Porphyromonas gingivalis $(P G)$ lipopolysaccharide (LPS) and fimbriae, and found that phytophenols such as curcumin, resveratrol (RE) and quercetin (QU) exhibited good antiinflammatory activity (13-15).

In the present study, we investigated the kinetic antioxidant activity of TC and related phenolic compounds in terms of induction period (IP) and propagation rate constant (Rp) values using differential scanning calorimetry (DSC) to monitor the polymerization of methyl methacrylate (MMA) initiated by thermal decomposition of azobisisobutyronitrile (AIBN) and benzoyl peroxide (BPO) under nearly anaerobic conditions $(16,17)$. The stoichiometric factor $(n$, the number of free radicals trapped by 1 mole of antioxidant) and the ratio of the rate constant of inhibition $\left(\mathrm{k}_{\mathrm{inh}}\right)$ and propagation $\left(\mathrm{k}_{\mathrm{p}}\right), \mathrm{k}_{\mathrm{inh}} / \mathrm{k}_{\mathrm{p}}$ of these compounds were determined. Our quantitative model allowed rationalization because it is based on kinetic and thermodynamic data under nearly anaerobic conditions. Details of the mechanisms responsible for the antioxidant and pro-/anti-inflammatory activity of tetracyclines have not yet been fully clarified. TC and MC may inhibit the levels of proinflammatory cytokines, ROS, nitric oxide synthase (NO) and matrix metalloprotease (MMP) in RAW264.7 cells. We also investigated the inhibitory effects of TC, MC, QU and RE and their combinations with or without visible light irradiation (VLI) on the expression of Cox 2, Tnfa, Nos 2 or Ho-1 mRNA in LPS-stimulated RAW264.7 cells. Recent studies have reported that QU and other phytophenols are effective for the treatment of periodontitis (18). In vitro and animal studies have also shown that QU has potential antimicrobial activity, and can reduce the levels of inflammatory markers and cholesterol, as well as inhibit bone loss $(19,20)$. Therefore, we also investigated the radical-scavenging and pro-/antiinflammatory activity of QU and RE as reference phenols for comparison with TC and MC.

\section{Materials and Methods}

Materials. TC, MC, QU were purchased from Tokyo Kasei Co. (Tokyo, Japan). trans-RE was obtained from Wako Pure Chemical Industries (Osaka, Japan). The chemical structures of these compounds are shown in Figure 1. Solutions of these compounds were prepared by dissolving each of them in dimethyl sulfoxide (DMSO), followed by dilution to the required concentrations using serum-free RPMI-1640 (Invitrogen Co., Carlsbad, CA, USA). Fetal bovine serum (FBS) was obtained from HyClone (Logan, UT, USA). Porphyromonas gingivalis (PG) ATCC33277 LPS was obtained from Wako Pure Chemical Industries.

Cell culture. The murine macrophage-like cell line RAW264.7, obtained from Dainippon Sumitomo Pharma Biomedical Co. Ltd. (Osaka, Japan), was used. The cells were cultured to a subconfluent state in RPMI-1640 medium supplemented with $10 \%$ FBS at $37^{\circ} \mathrm{C}$ and $5 \% \mathrm{CO}_{2}$ in air, washed, and then incubated overnight in serum- 
Table I. Antioxidant activity of tetracycline, a-tocopherol, trolox, quercetin and resveratrol determined using the induction period method.

\begin{tabular}{|c|c|c|c|c|c|c|c|}
\hline System & Antioxidant & $\begin{array}{l}\text { Con } \\
\mathrm{mM}\end{array}$ & $\begin{array}{l}\mathrm{IP}^{*} \\
\mathrm{~min}\end{array}$ & $\begin{array}{l}\text { Max. peak } \\
\mathrm{mcal} / \mathrm{min}\end{array}$ & $\begin{array}{l}\text { Time at } \\
\text { max. peak } \\
\text { min }\end{array}$ & $\begin{array}{l}\mathrm{Rp}^{* *} \\
\% / \min \end{array}$ & $\begin{array}{c}\text { Conversion } \\
\%\end{array}$ \\
\hline \multirow[t]{12}{*}{ AIBN } & Control & & 3.59 & 203.24 & 43.42 & 1.36 & 94.05 \\
\hline & Tetracycline & 0.1 & 3.68 & 203.00 & 43.40 & 1.36 & 94.02 \\
\hline & & 1 & 4.21 & 203.16 & 41.40 & 1.36 & 93.95 \\
\hline & & 2 & 4.43 & 189.29 & 42.93 & 1.30 & 94.77 \\
\hline & & 4 & 4.95 & 190.67 & 47.70 & 1.33 & 95.02 \\
\hline & & 5 & 4.99 & 196.49 & 43.73 & 1.39 & 95.21 \\
\hline & $\alpha$-tocopherol & 1 & 8.28 & 192.39 & 47.83 & 1.32 & 93.28 \\
\hline & Trolox & 1 & 9.14 & 189.54 & 49.35 & 1.37 & 93.95 \\
\hline & Quercetin & 0.1 & 4.56 & 199.74 & 41.47 & 1.39 & 93.01 \\
\hline & & 1 & 9.90 & 163.20 & 48.62 & 1.22 & 93.6 \\
\hline & Resveratrol & 0.1 & 4.87 & - & 42.52 & 1.38 & 91.13 \\
\hline & & 1 & 10.44 & 146.75 & 51.25 & 1.15 & 94.14 \\
\hline \multirow[t]{12}{*}{$\mathrm{BPO}$} & Control & & 7.20 & 210.51 & 60.23 & 0.92 & 95.48 \\
\hline & Tetracycline & 0.1 & 7.54 & 215.34 & 58.62 & 0.87 & 95.44 \\
\hline & & 1 & 7.23 & 217.18 & 59.55 & 0.89 & 95.95 \\
\hline & & 2 & 7.72 & 180.19 & 60.87 & 0.83 & 96.29 \\
\hline & & 4 & 10.12 & 174.29 & 64.93 & 0.90 & 94.5 \\
\hline & & 5 & 10.40 & 166.26 & 64.83 & 0.84 & 96.82 \\
\hline & $\alpha$-tocopherol & 1 & 8.42 & 195.54 & 60.60 & 0.85 & 93.06 \\
\hline & Trolox & 1 & 7.89 & 194.56 & 61.10 & 0.88 & 96,20 \\
\hline & Quercetin & 0.1 & 10.38 & 214.20 & 61.07 & 0.92 & 94.5 \\
\hline & & 1 & 19.31 & 164.86 & 72.18 & 0.81 & 94.42 \\
\hline & Resveratrol & 0.1 & 9.22 & 209.47 & 59.72 & 0.92 & 94.34 \\
\hline & & 1 & 25.67 & 150.62 & 80.55 & 0.82 & 93.12 \\
\hline
\end{tabular}

The values were determined based on the DSC data reported previously (23) using differential scanning calorimetry (DSC) monitoring of the polymerization of MMA (9.4 mol) initiated by thermal decomposition of AIBN (azobisisobutyronitrile) or BPO (benzoyl peroxide) under nearly anaerobic conditions at $70^{\circ} \mathrm{C}$. The procedure is described in the text. Conversion, $84.9-96.9 \%$. *Induction period, **Propagation rate constant. The values are the means for two or three independent experiments. Standard errors were $<15 \%$.

free RPMI-1640. They were then washed again and treated with the test samples for cytotoxicity and real-time polymerase chain reaction $(\mathrm{PCR})$.

Preparation of total RNA and real-time PCR. The preparation of total RNA and the procedure of real-time PCR have been described previously (21). In brief, RAW264.7 cells in NUNC 96-flat-well-type microculture plates $\left(10^{5}\right.$ cells per well) were pretreated for $30 \mathrm{~min}$ with or without $0.4 \mathrm{mM} \mathrm{TC}$ or MC, or with or without $10 \mu \mathrm{M} \mathrm{RE}$ or QU, and then incubated for $3.5 \mathrm{~h}$ with or without PG-LPS. During the pretreatment, some of these wells were subjected to $3 \mathrm{VL}$ irradiation doses for $3 \mathrm{sec}$. The VL lamp was a G-Light Prima II Plus (GC Corp., Tokyo, Japan, $\lambda_{\max }=465 \pm 10 \mathrm{~nm}$, irradiation dose $\left.1,200 \mathrm{~mW} / \mathrm{cm}^{2}\right)$. The total cellular RNA was then isolated using a RNeasy Plus Micro Kit (Qiagen Japan Co. Ltd., Tokyo, Japan) in accordance with the instruction manual. cDNA was synthesized from $2 \mu \mathrm{g}$ total RNA of each sample by random priming using a High Capacity RNA-to-cDNA Kit (Life Technologies, Tokyo, Japan). Reaction mixtures without the reverse transcriptase were used as a negative control. An aliquot of each cDNA synthesis reaction mixture was diluted and used for real-time PCR quantification. An equal-volume aliquot of each cDNA was mixed, serially diluted, and used as a standard. TaqMan probes/primers for Cox 2, Nos 2, Tnfa, Ho- 1 and 18 s rRNA and the PCR enzyme mix for real-time PCR were purchased from Life Technologies Japan. Real- time PCR quantification was performed in triplicate using the GeneAmp Sequence Detection System 5700 software (Life Technologies, Japan) in accordance with the manufacturer's instructions. The relative amount of target was calculated from standard curves generated for each PCR, and quantitative data with coefficients of variance of less than $10 \%$ were used for further analyses. Each calculated amount of mRNA was standardized by reference to that for $18 \mathrm{~s}$ rRNA. Data were expressed as means of three independent experiments. Statistical analyses were performed using Student's $t$-test and one-way ANOVA. Regression analysis was performed with StatMate III (ATMS Co., Ltd., Tokyo, Japan).

Radical-scavenging activity. The experiments to determine the antioxidant activity of carotenoids were performed using a DSC as reported previously $(16,22)$. Briefly, about $10 \mu \mathrm{l}$ of experimental resin (MMA: 9.12-9.96 g) with $1.0 \mathrm{~mol} \% \mathrm{AIBN}$ or BPO and $0-0.5$ mol\% carotenoid were loaded into an aluminum sample container and sealed by applying pressure. The container was then placed in a DSC (model DSC 3100; Mac Science Co., Tokyo, Japan) kept at $70^{\circ} \mathrm{C}$, and the thermal changes induced by polymerization were recorded for the appropriate time periods. The heat due to the polymerization of MMA was $13.0 \mathrm{kcal} / \mathrm{mol}$. The conversion of all samples (\%) was calculated from the DSC thermograms using the integrated heat evoked by MMA polymerization. 
Table II. Antioxidant activities (stoichiometric factor, $n$; the rate constant of inhibition and propagation, $k_{\text {inh }} / k_{p}$ ) for tetracycline and related phenolic compounds using the induction period method in the 2,2'-azobisisobutyronitrile, AIBN or benzoyl peroxide, BPO-methyl methacrylate, MMA polymerization system.

\begin{tabular}{|c|c|c|c|c|c|}
\hline \multirow[b]{2}{*}{ Antioxidant } & \multirow[b]{2}{*}{ Con.(mM) } & \multicolumn{2}{|c|}{ AIBN system } & \multicolumn{2}{|c|}{ BPO system } \\
\hline & & $n$ & $\mathrm{k}_{\mathrm{inh}} / \mathrm{k}_{\mathrm{p}}$ & $n$ & $\mathrm{k}_{\mathrm{inh}} / \mathrm{k}_{\mathrm{p}}$ \\
\hline \multirow[t]{5}{*}{ Tetracycline } & 0.1 & 0.3 & 817.4 & 0.5 & 391.7 \\
\hline & 1 & 0.2 & 118.9 & 0.1 & 249.3 \\
\hline & 2 & 0.1 & 91.4 & 0.1 & 231.6 \\
\hline & 4 & 0.1 & 55.3 & 0.2 & 38.0 \\
\hline & 5 & 0.1 & 54.6 & 0.1 & 37.1 \\
\hline$\alpha$-Tocopherol & 1 & 1.7 & 15.0 & 0.2 & 96.9 \\
\hline Trolox & 1 & 1.9 & 13.2 & 0.1 & 164.9 \\
\hline \multirow[t]{2}{*}{ Quercetin } & 0.1 & 3.3 & 74.0 & 2.7 & 34.2 \\
\hline & 1 & 1.8 & 15.0 & 4.1 & 10.3 \\
\hline \multirow[t]{2}{*}{ Resveratrol } & 0.1 & 4.3 & 36.6 & 2.7 & 53.7 \\
\hline & 1 & 2.3 & 12.7 & 2.5 & 6.6 \\
\hline
\end{tabular}

The values were calculated from the results of Table I using equations 1 and 2, respectively.

Measurement of the stoichiometric factor ( $n$ ) and inhibition rate constant $\left(k_{i n h}\right)$. The $n$ value in equation 1 can be calculated from the induction period in the presence of inhibitors (antioxidants) as:

$$
n=\mathrm{R}_{\mathrm{i}}[\mathrm{IP}] /[\mathrm{IH}]
$$

where IP is the induction period in the presence of a carotenoid inhibitor (IH). The number of moles of BPO or AIBN radicals trapped by the antioxidant was calculated with respect to $1 \mathrm{~mol}$ of the inhibitor moiety. The initiation rate $\left(\mathrm{R}_{\mathfrak{i}}\right)$ for AIBN and BPO at $70^{\circ} \mathrm{C}$ was $5.56 \times 10^{-6} \mathrm{~mol}^{1-1} \mathrm{sec}^{-1}$ and $2.28 \times 10^{-6} \mathrm{~mol} \mathrm{l}^{1-1} \mathrm{sec}^{-1}$, respectively, calculated on the basis of $n=2.0$ for 2,6-di-tert-butyl4-methoxyphenol $(16,22,23)$.

The $\mathrm{k}_{\mathrm{inh}}$ is given by

$$
\mathrm{k}_{\mathrm{inh}} / \mathrm{k}_{\mathrm{p}}=([\mathrm{MMA}] /[\mathrm{IP}] \times[\mathrm{Rp}])(\mathrm{eq} .2)
$$

where $\mathrm{k}_{\mathrm{p}}$ is the propagation rate constant, and MMA, IP and the rate of propagation (Rp) are defined above. A $k_{p}$ value of $9301 \mathrm{~mol}$ ${ }^{-1} \mathrm{sec}^{-1}$ was used in this work (23).

\section{Results}

Radical-scavenging activity. First, we examined the kinetic radical-scavenging activity of TC in comparison with $\alpha$ tocopherol (TOC), trolox, QU and RE. We used the induction period method in order to clarify the radicalscavenging mechanism of interaction between these phenol compounds and the AIBN (cyano-isopropyl, R•) and BPO (benzencarboxy, $\mathrm{PhCOO} \cdot$ ) radicals. The results are shown in Tables I and II.

Because there was a very small amount of air in the DSC sample container, induction time was also observed in the controls, since oxygen acts as an inhibitor and therefore, the
IP value was determined as $\mathrm{IP}_{\text {sample }} \mathrm{IP}_{\text {control }}$. The $n$ value for these compounds was calculated using eq. 1 and the $\mathrm{k}_{\mathrm{inh}} / \mathrm{k}_{\mathrm{p}}$ value was calculated using eq. 2. These results are shown in Table II. The $n$ value of $0.1-0.5 \mathrm{mM}$ TC in the AIBN system was 0.1-0.3, whereas that in the BPO system was 0.1-0.5. Fully oxidized monophenol should have an $n$ value of 2 , but the $n$ for TC was markedly less than 1 . Therefore, TC was not a potent antioxidant. Also, the $\mathrm{k}_{\text {inh }} / \mathrm{k}_{\mathrm{p}}$ value for 0.1-5 mM TC in the AIBN system was 54-817, whereas that in the BPO system was 37-392. The $\mathrm{k}_{\mathrm{inh}} / \mathrm{k}_{\mathrm{p}}$ value for $\mathrm{TC}$ increased as the concentration increased. In contrast, the $n$ value for $0.1 \mathrm{mM}$ QU and RE in the AIBN system was 3.3 and 4.3, respectively, whereas that in the BPO system was 2.7 and 4.3 , respectively. The $n$ value for $1 \mathrm{mM}$ QU in the two systems was 1.8 and 4.1, respectively, whereas the corresponding value for RE was 2.3 and 2.5, respectively. The $n$ value of these compounds was 24. The $n$ value of fully oxidized RE and QU should be 4 .

The $\mathrm{k}_{\mathrm{inh}} / \mathrm{k}_{\mathrm{p}}$ value for $0.1 \mathrm{mM} \mathrm{QU}$ and $\mathrm{RE}$ in the two systems was 34-74, whereas that for $1 \mathrm{mM}$ was 7-15. The antioxidant activity of QU and RE was one order greater than that of TC. Interestingly, the $n$ and $\mathrm{k}_{\mathrm{inh}} / \mathrm{k}_{\mathrm{p}}$ values for TOC and trolox showed great difference between the AIBN and BPO systems. The $n$ value for these compounds in the AIBN system was about 2, whereas that in the BPO system was 0.10.2. Also, the $\mathrm{k}_{\mathrm{inh}} / \mathrm{k}_{\mathrm{p}}$ value for TOC and trolox in the BPO system was 97-165, whereas that in the AIBN system was 1315. The lower antioxidant activities of TOC in the BPO system may be interpreted in terms of steric hindrance due to substituents of TOC, retarding the transfer of hydrogen to BPO (benzencarboxy, $\mathrm{PhCOO} \cdot$ ) radicals, and electronic effects that increase $\mathrm{k}_{\mathrm{inh}}$ by stabilization of the TOC phenoxyl radicals. Also, it can be interpreted by the fact that the 

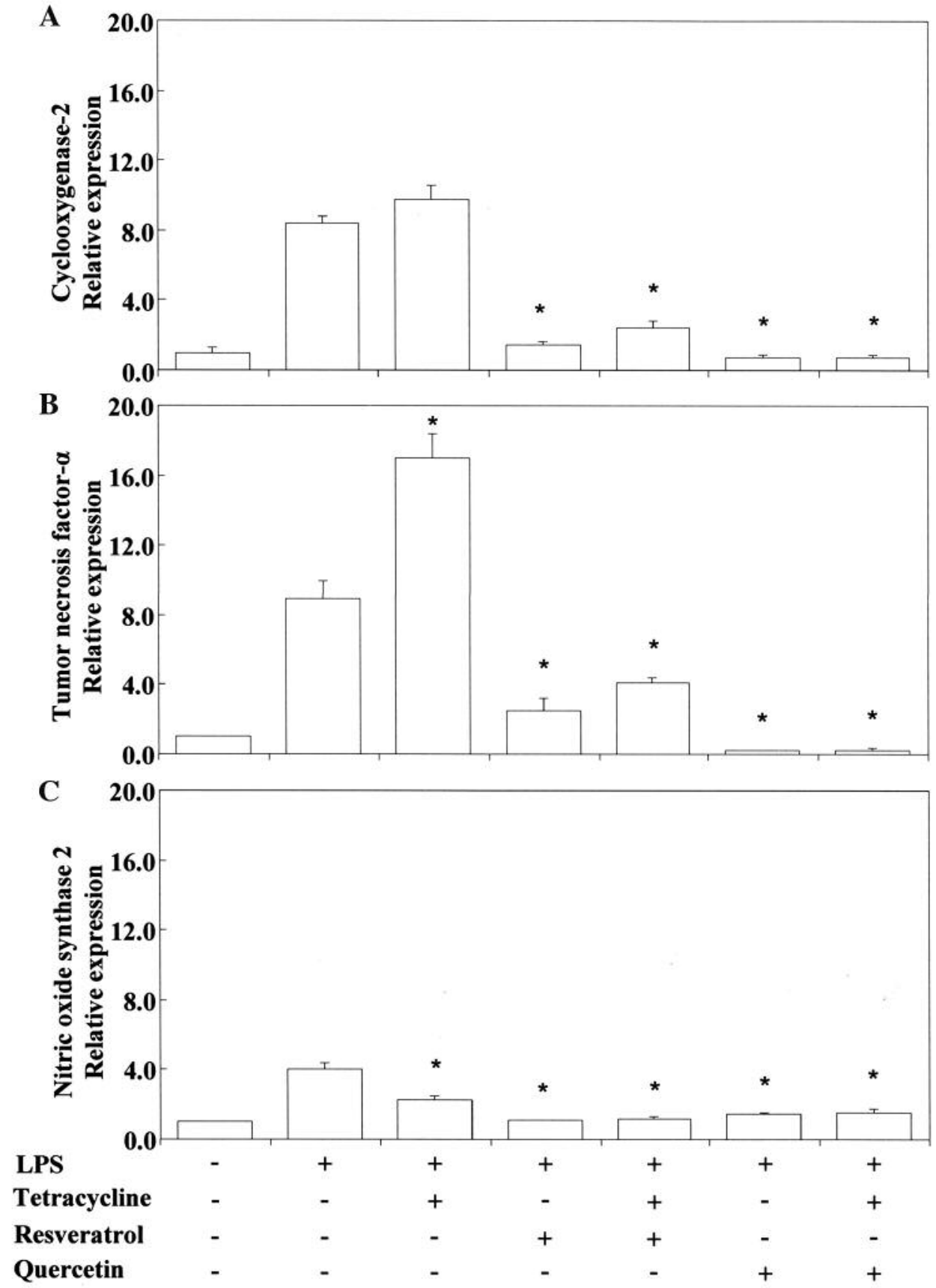

Figure 2. Inhibitory effects of tetracycline in combination with resveratrol or quercetin on the expression of Cox $2(A)$, Tnfa $(B)$ and Nos $2(C) m R N A$ in Porphyromonas gingivalis (PG)-LPS-stimulated RAW264.7 cells. The cells were pretreated for $30 \mathrm{~min}$ with $0.4 \mathrm{mM}$ minocycline, $10 \mu \mathrm{M}$ resveratrol or $10 \mu \mathrm{M}$ quercetin, and $0.4 \mathrm{mM}$ tetracycline with or without resveratrol or quercetin, and then incubated for $3.5 \mathrm{~h}$ with or without $100 \mathrm{ng} / \mathrm{ml} P G$ LPSt. Total RNAs were prepared, cDNAs were synthesized, and the expression levels of Cox2, Tnfa and Nos 2 mRNA were determined by real-time polymerase chain reaction and standardized against the expression of $18 s$ rRNA. The results are presented as means \pm standard error (SE) of three independent experiments, $S E<15 \%$. *Significantly different at $p<0.01 \mathrm{vs}$. LPS group.

initiation rate $\left(\mathrm{R}_{\mathrm{i}}\right)$ of the AIBN (cyano-isopropyl, $\mathrm{R} \cdot$ ) radical derived from AIBN was about two-fold greater than that of the corresponding BPO (benzencarboxy, PhCOO·) radicals. TOC and trolox possess higher intrinsic scavenging potency for AIBN radicals, resulting from their large $n$ value. Our results suggested that these oxygen center radicals in biological systems may be scavenged less extensively by TOC (24). In the BPO system, the $\mathrm{k}_{\mathrm{inh}} / \mathrm{k}_{\mathrm{p}}$ value at $1 \mathrm{mM}$ 

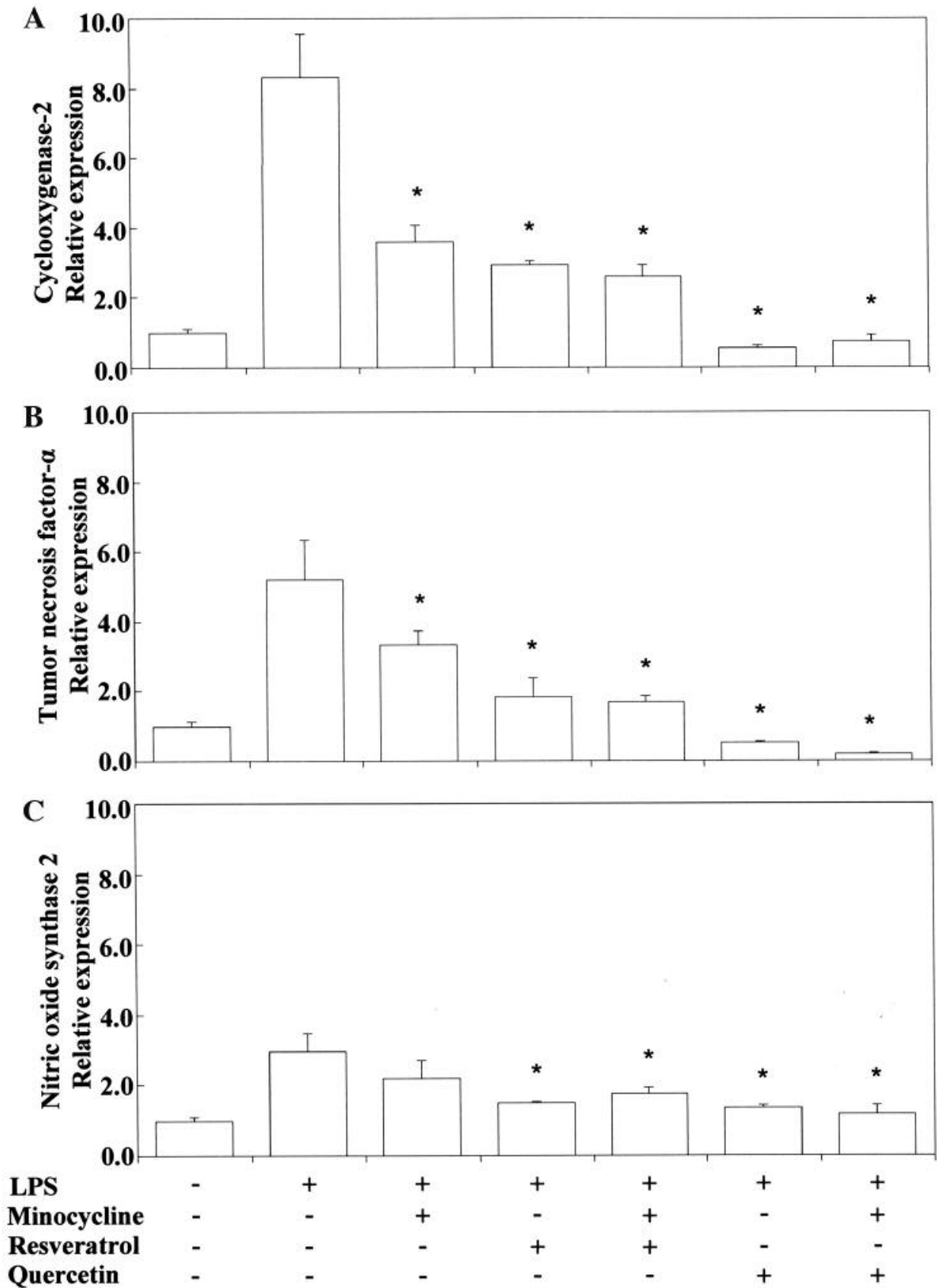

Figure 3. Inhibitory effects of minocycline in combination with resveratrol or quercetin on the expression of Cox $2(A)$, Tnfa $(B)$ and Nos $2(C)$ mRNA in Porphyromonas gingivalis (PG)-LPS-stimulated RAW264.7 cells. The cells were pretreated for $30 \mathrm{~min}$ in $0.4 \mathrm{mM}$ minocycline, $10 \mu \mathrm{M}$ resveratrol or $10 \mu \mathrm{M}$ quercetin, and $0.4 \mathrm{mM}$ tetracycline with or without resveratrol or quercetin, and then incubated for $3.5 \mathrm{~h}$ with or without $100 \mathrm{ng} / \mathrm{ml} P G$ LPS. Total RNAs were prepared, cDNAs were synthesized, and the expression levels of Cox 2 , Tnfa and Nos 2 mRNA were determined by real-time polymerase chain reaction and standardized against the expression of $18 s$ rRNA. The results are presented as means \pm standard error (SE) of three independent experiments, $S E<15 \%$. *Significantly different at $p<0.01 \mathrm{vs}$. LPS group.

increased in the order $\mathrm{RE} \quad(6.6)>\mathrm{QU} \quad(10.3)>\mathrm{TOC}$ (96.9)>trolox (164.9)> TC (249.3). Also, the $\mathrm{k}_{\mathrm{inh}}$ value $\left(\mathrm{mol}^{-}\right.$ ${ }^{1} \mathrm{sec}^{-1}$ ) for TC, trolox, TOC, QU and RE declined in the order $2.3 \times 10^{5}>1.5 \times 10^{5}>9.0 \times 10^{4}>9.3 \times 10^{3}>6.1 \times 10^{3}$. The relationship between $\mathrm{k}_{\mathrm{inh}} / \mathrm{k}_{\mathrm{p}}$ and the square root of TC concentration $\left(\mathrm{C}^{1 / 2}\right)$ was investigated and a significant linear relationship was observed in the AIBN $\left(r^{2}=0.68\right)$ and BPO $\left(r^{2}=0.96\right)$ systems, respectively. 

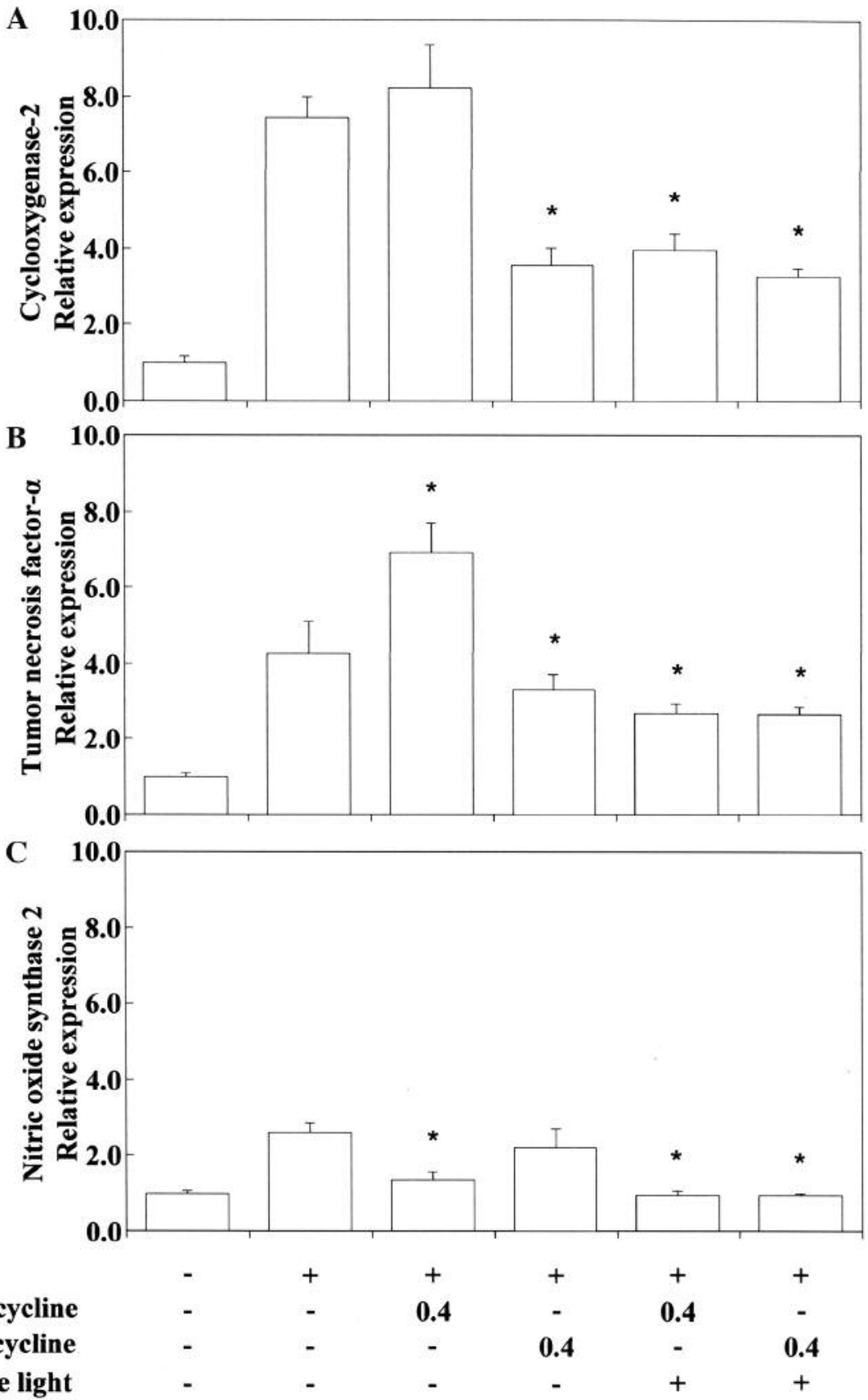

Figure 4. Inhibitory effects of tetracycline and minocycline upon exposure to visible-light irradiation on the expression of Cox2 (A), Tnfa (B) and Nos 2 mRNAs $(C)$ in Porphyromonas gingivalis (PG)-LPS-stimulated RAW264.7 cells. The cells were pretreated for $30 \mathrm{~min}$ with $0.4 \mathrm{mM}$ tetracycline or $0.4 \mathrm{mM}$ minocycline with or without exposure to visible-light irradiation for $3 \mathrm{~s}$, and then incubated for $3.5 \mathrm{~h}$ with or without $100 \mathrm{ng} / \mathrm{ml}$ PG-LPS. Total RNAs were prepared, cDNAs were synthesized, and the expression levels of Cox2, Tnfa and Nos 2 mRNA were determined by realtime polymerase chain reaction and standardized against the expression of $18 \mathrm{~s} r R N A$. The results are presented as means \pm standard error (SE) of three independent experiments, $S E<15 \%$. *Significantly different at $p<0.01 \mathrm{vs}$. LPS group.

The $\mathrm{k}_{\text {inh }} / \mathrm{k}_{\mathrm{p}}$ for TC in the BPO system is given by

$\mathrm{k}_{\mathrm{inh}} / \mathrm{k}_{\mathrm{p}}=457.1( \pm 35.4)-192.2( \pm 22.9) \mathrm{C}^{1 / 2}(\mathrm{n}=5, p<0.01)$

(eq.3)
Unsaturated fatty acids are highly susceptible to lipid peroxidation. Hydrogen $(\mathrm{H})$ of phenolic $\mathrm{O}-\mathrm{H}$ groups can be abstracted by oxygen-centered radicals such as the peroxy $(\mathrm{LOO} \cdot)$, alkoxy ( $\left.\mathrm{LO}^{\cdot}\right)$ and hydroxy $\left(\mathrm{OH}^{\circ}\right)$ radicals; the 

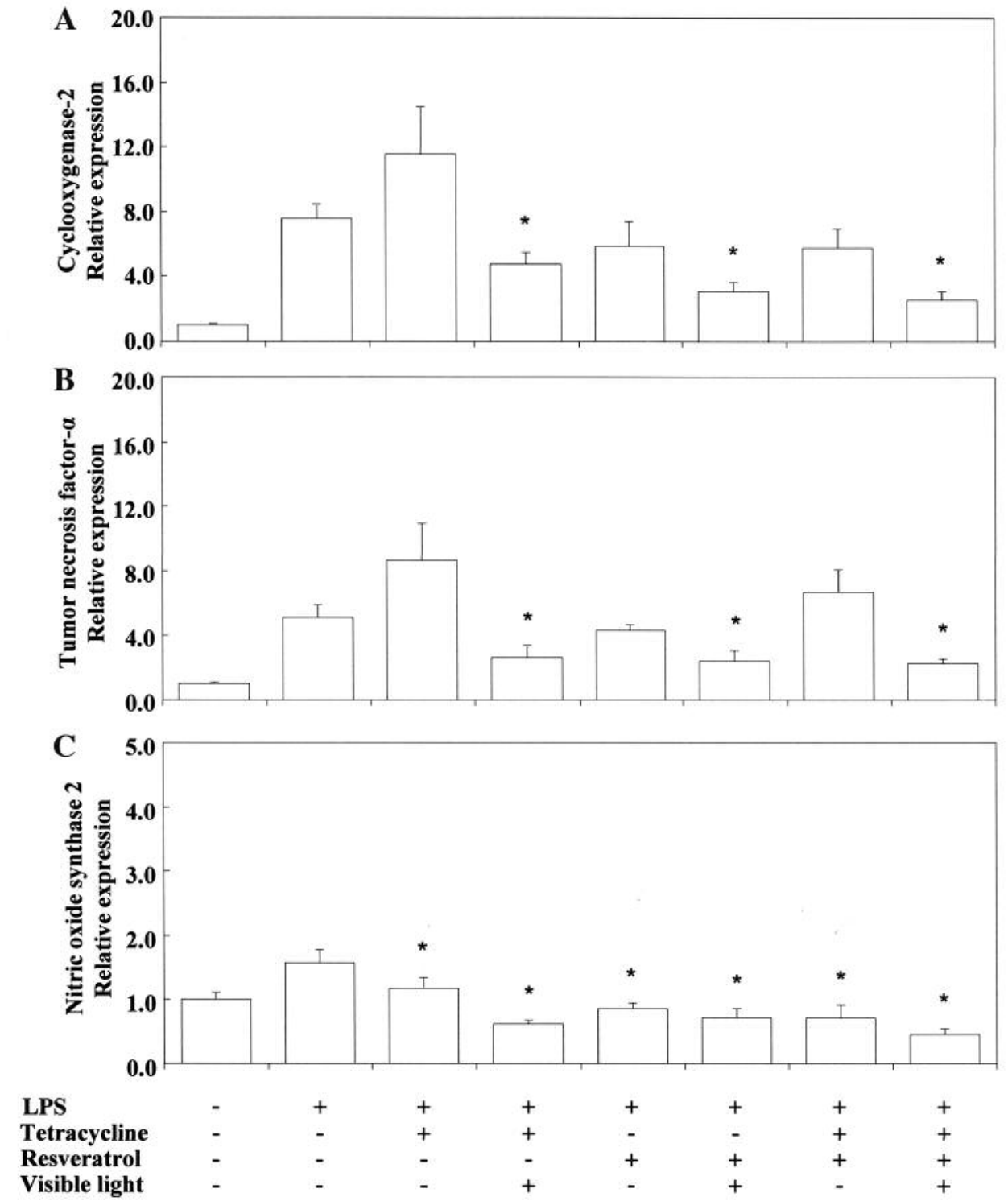

Figure 5. Effect of visible-light irradiation on Cox2 (A), Tnfa (B) and Nos2 (C) mRNA expression in RAW264.7 cells consecutively stimulated with tetracycline, and/or resveratrol and Porphyromonas gingivalis (PG)-LPS-stimulated. The cells were pretreated for $30 \mathrm{~min}$ with $0.4 \mathrm{mM}$ tetracycline or $10 \mu \mathrm{M}$ resveratrol, or tetracycline with or without resveratrol, and with or without exposure to visible-light irradiation for $3 \mathrm{~s}$. They were then incubated for $3.5 \mathrm{~h}$ with or without $100 \mathrm{ng} / \mathrm{ml} P G-L P S$, and total RNAs were prepared. cDNA was synthesized, and the expression levels of Cox2, Tnfa and Nos 2 mRNA were determined by real-time polymerase chain reaction and standardized against the expression of $18 \mathrm{~s} r R N A$. The results are presented as means \pm standard error (SE) of three independent experiments, SE<15\%. *Significantly different at p $<0.01 \mathrm{vs.} \mathrm{LPS} \mathrm{group.}$

unsaturated region in the lipid chain can also react with singlet oxygen to form lipid peroxides. Eq. 3 suggested that TC may act as a chain-breaking radical scavenger, although its scavenging activity was very low.

Pro-/anti-inflammatory activity. Next, we investigated the anti-inflammatory activity of TC and related phenol compounds on LPS-stimulated RAW264.7 cells. Figures 2 and 3 show that LPS-stimulated Cox 2 and Tnf $\alpha$ mRNA expression was upregulated by TC. Nos 2 mRNA expression was inhibited by TC. MC strongly inhibited LPS-stimulated Cox 2 and Tnfa mRNA expression. However, MC did not inhibit Nos 2 mRNA expression. RE and QU markedly suppressed Cox2, Tnfa and Nos 2 mRNA expression regardless of treatment with TC or MC. No synergistic activity was demonstrated between TC or MC and RE or 

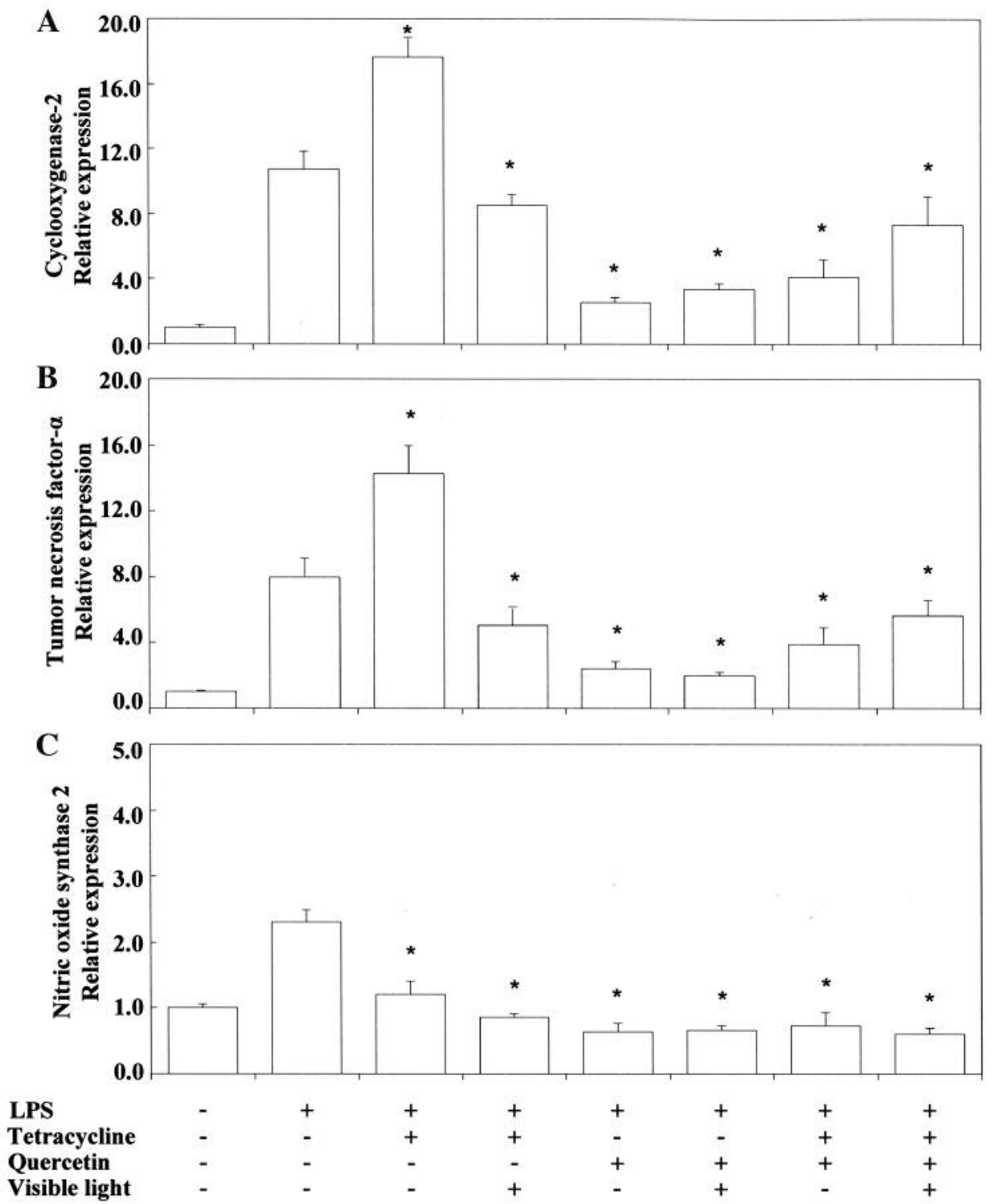

Figure 6. Effect of visible-light irradiation on Cox2 (A), Tnfa (B) and Nos2 (C) mRNA expression in RAW264.7 cells consecutively stimulated with tetracycline and quercetin in combination and Porphyromonas gingivalis (PG)-LPS. The cells were pretreated for $30 \mathrm{~min}$ in $0.4 \mathrm{mM}$ tetracycline or $10 \mu \mathrm{M}$ quercetin, or tetracycline with or without quercetin, and with or without exposure to visible-light irradiation for $3 \mathrm{~s}$. They were then incubated for $3.5 \mathrm{~h}$ with or without $100 \mathrm{ng} / \mathrm{ml} P G-L P S$, and total RNAs were prepared.cDNAs were synthesized, and the expression levels of Cox2, Tnfa and Nos 2 mRNA were determined by real-time polymerase chain reaction and standardized against the expression of $18 \mathrm{~s} r \mathrm{RNA}$. The results are presented as means \pm standard error (SE) of three independent experiments, $S E<15 \%$. *Significantly different at p<0.01 vs. LPS group.

QU. We also tested the influence of VLI on LPS-stimulated Cox-2 and Tnf $\alpha$ mRNA expression in the cells. Figure 4 shows that the TC-stimulated up-regulation of these mRNAs was markedly inhibited by VLI. The effect of MC was not affected by VLI. We further investigated whether the synergistic anti-inflammatory activity between TC and RE or QU affected LPS-stimulated Cox2, Tnf $\alpha$ and Nos2 mRNA expression by VLI. Figures 5 and 6 show that the anti- inflammatory effects of TC and RE were enhanced by VLI, but that QU did not have an enhancing effect and showed pro-inflammatory properties. These observations suggested to us the necessity of investigation whether the degradation of TC may stimulate the production of secondary biological active products by VLI. Therefore, to clarify the mechanism responsible for the anti-inflammatory effect of VL-irradiated TC, we investigated whether VLI stimulated Ho- 1 expression 


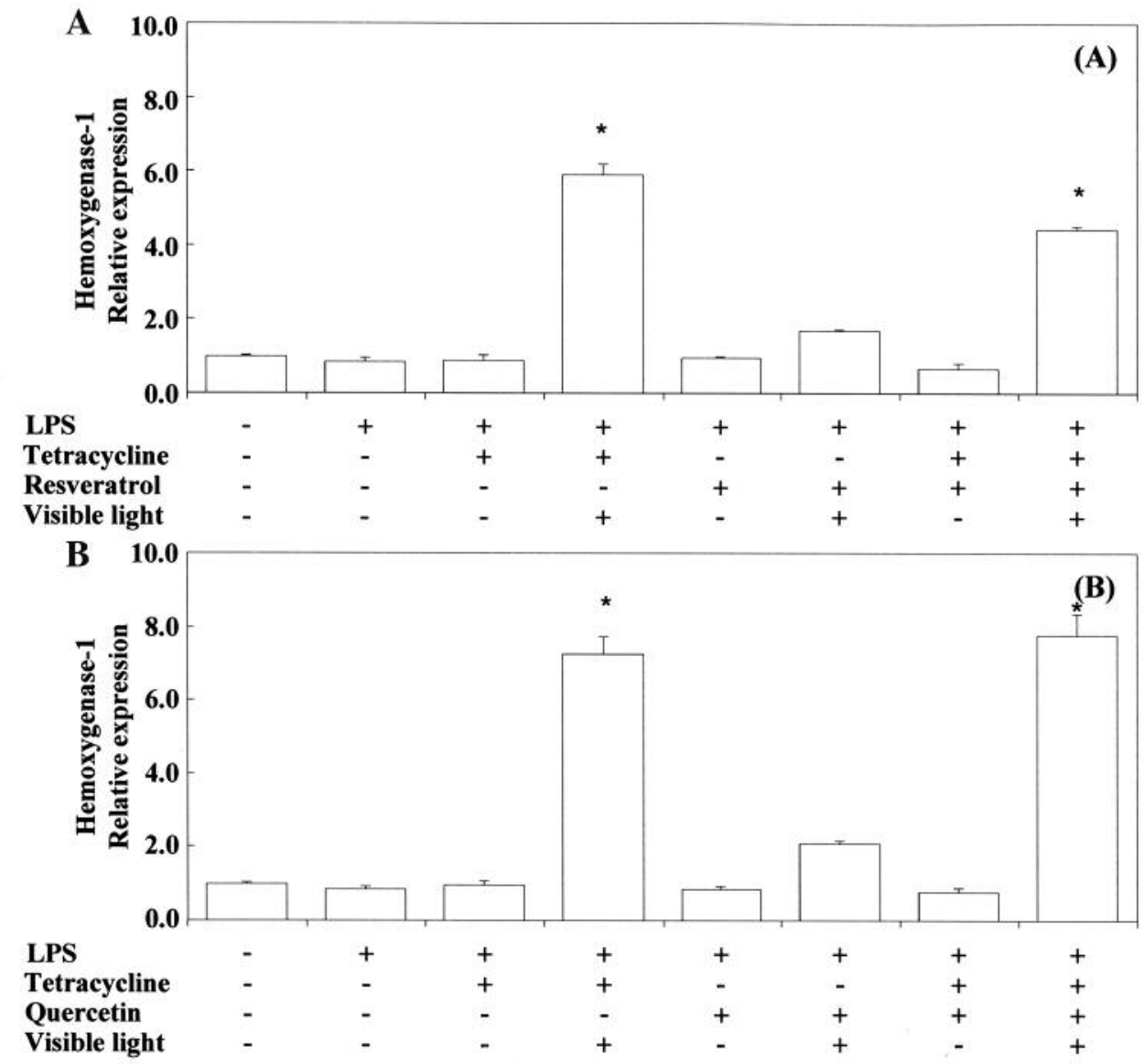

Figure 7. Effect of visible-light irradiation on tetracycline and resveratrol (A) and quercetin (B) in combination in RAW264.7 cells stimulated with Porphyromonas gingivalis (PG)-LPS on Ho-1 mRNA expression. The cells were pretreated for 30 min with $0.4 \mathrm{mM}$ tetracycline or $10 \mu \mathrm{M}$ resveratrol or $10 \mu M$ quercetin, or tetracycline with or without resveratrol or quercetin, and with or without exposure to visible-light irradiation for $3 \mathrm{~s}$. They were then incubated for $3.5 \mathrm{~h}$ with or without $100 \mathrm{ng} / \mathrm{ml} P G-L P S$, and total RNAs were prepared.cDNAs were synthesized, and the expression levels of Ho-1 mRNA were determined by real-time polymerase chain reaction and standardized against the expression of $18 s$ rRNA. The results are presented as means \pm standard error (SE) of three independent experiments, $S E<15 \%$. *Significantly different at $p<0.01 \mathrm{vs.} \mathrm{LPS} \mathrm{group.}$

in the same sample. Figures 7 and 8 show that stimulation of TC activated by VLI greatly up-regulated the expression of Ho-1 mRNA (approx. 4-fold). In contrast, except for TC activation by VLI, Ho- 1 expression was not affected by activation of any of the other compounds tested by VLI.

\section{Discussion}

Oxidative stress caused by bacterial LPS, chemicals, light, redox, $\mathrm{pH}$ etc. has been implicated in the pathology of many disease and conditions including cardiovascular disease, periodontal diseases, diabetes, inflammatory conditions, cancer and aging. Antioxidants may reduce oxidative stress by scavenging free radicals and ROS, and inhibiting lipid peroxidation (25). Thus, the radical-scavenging activity of tetracycline and related phenols is a very important aspect of their biological activity. TCs are complex molecules with a unique chemically connected four-ring system with multiple ionizable functional groups (Figure 1). The dimethyl amino group at the $\mathrm{C} 4$ carbon, like that in $\mathrm{MC}$, has been shown to be necessary for increased antioxidant activity. The antioxidant activity of tetracycline is probably lower than that of $\mathrm{MC}$, since the phenolic $\mathrm{O}-\mathrm{H}$ bond dissociation enthalpy (O-H-BDE) of aminophenols is lower than that of the parent phenol like TC. Cell-free assays have shown that the $\mathrm{IC}_{50}$ of the antioxidant activity of $\mathrm{MC}$ is $3-40 \mu \mathrm{M}$, that is $200-300$ times more potent than that of TC. The antioxidant activity of MC is comparable to that of TOC and trolox (26). However, no previous report has documented the kinetic radical-scavenging activity of TC. Our DSC studies have made it possible to examine the radical-scavenging activities of very small antioxidant compounds such as $\beta$-carotene and 


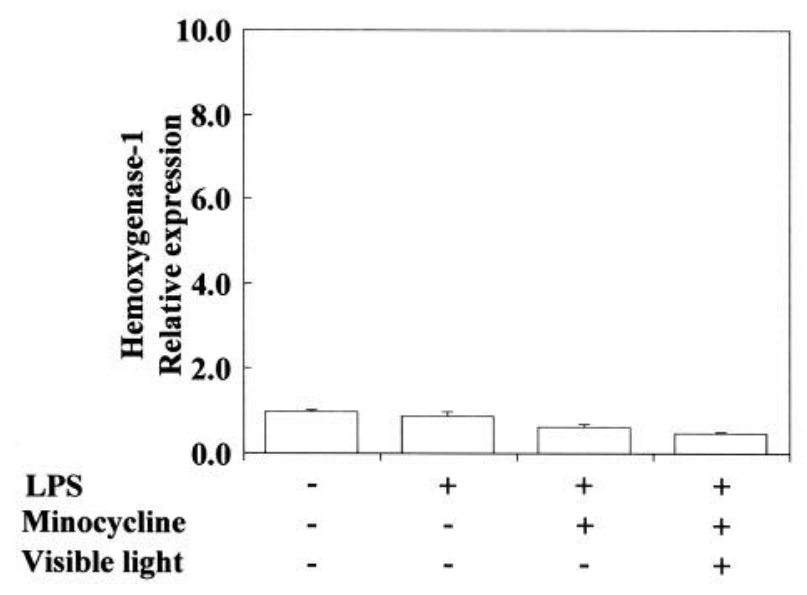

Figure 8. Minocycline does not induce Ho-1 mRNA expression upon exposure to visible-light irradiation in Porphyromonas gingivalis $(P G)$ LPS-stimulated RAW264.7 cells. The cells were pretreated for $30 \mathrm{~min}$ with $0.4 \mathrm{mM}$ minocycline with or without exposure to visible-light irradiation for $3 \mathrm{~s}$, and then incubated for $3.5 \mathrm{~h}$ with or without 100 $n g / m l$ PG-LPS. Total RNAs were then prepared, cDNAs were synthesized, and the expression levels of Ho-1 mRNA were determined by real-time polymerase chain reaction and standardized against the expression of $18 \mathrm{~s} r R N A$. The results are presented as means \pm standard error (SE) of three independent experiments, $S E<15 \%$.

lycopene (17). The oxygen tension under a 15-torr oxygen atmosphere is similar in many tissues $(27,28)$. The antioxidant activity of phenolic compounds may therefore differ considerably from that evaluated previously at high oxygen concentration using the induction period approach $(29,30)$. In general, phenols are chain-breaking antioxidants. In the present study, TC with bulky side chains was clearly shown to be a chain-breaking antioxidant, as shown by eq. 3 .

The antibacterial and anti-inflammatory efficacy of therapeutically relevant antibiotics such as tetracyclines may be investigated in terms of ROS generation related to their antibacterial, anti-apoptotic, and anti-protease activities (1). Although free radicals abstract the hydrogen atom from the phenolic $\mathrm{OH}$ group in TC, TC immediately forms a relatively stable phenol-derived free radical, as estimated from the high $\mathrm{k}_{\text {inh }}$ value of TC. The antioxidant activity of TC is very low, and TC at the cellular level may act as a non-antioxidant, as assumed from its very low $n$ value. Therefore, the cellular functions of TC may be independent of its antioxidant/radicalscavenging activity.

TC, but not MC, QU and RE, increased Tnf $\alpha$ mRNA expression considerably (overexpression) and increased Cox2 mRNA expression slightly but significantly, whereas TC suppressed Nos 2 mRNA expression in LPS-stimulated cells. In contrast, MC significantly down-regulated expression of $\operatorname{Cox} 2$, Tnf $\alpha$ and Nos 2 mRNAs, indicating its anti-inflammatory activity. Interestingly, the expression of
Cox 2 and Tnf $\alpha$ mRNA in the presence of TC clearly differed from that in the presence of MC. MC, but not TC, showed anti-inflammatory activity at low concentrations. TC at low concentrations may have acted as a pro-oxidant, as estimated from its very low $\mathrm{n}$ value and high $\mathrm{k}_{\text {inh }}$ value.

Attur et al. have reported that in murine macrophages (RAW264.7) stimulated with LPS, tetracyclines (MC and doxycycline) at low concentrations inhibited NO release and increased PGE2 production, and also that the enhancement of PGE2 production in RAW264.7 cells by tetracyclines was accompanied by accumulation of both Cox 2 mRNA and cytosolic Cox 2 protein (6). Our results indicated that TC alone upregulated Cox 2 mRNA expression slightly but significantly and up-regulated Tnf $\alpha$ mRNA expression greatly. DC has much closer structural similarity to TC than to MC, since DC does not possess substituents of the dimethylamino group at the para position in the phenol ring (Figure 1). The antioxidant and anti-inflammatory activity of DC is thought to be similar to that of TC. The expression of Cox2 and Tnf $\alpha$ mRNA in the presence of low concentrations of TC in LPSstimulated RAW264.7 cells differed greatly from those in the presence of MC, perhaps being attributable to their antioxidant activity. The antioxidant activity of $\mathrm{MC}$ has been reported to be greater than that of TC or DC (23). In LPS-stimulated cells, $\mathrm{MC}$ at $0.4 \mathrm{mM}$ suppressed the mRNA expression of Cox 2 and Tnfo whereas TC at $0.4 \mathrm{mM}$ suppressed that of Nos2, indicating that these compounds exert strong antiinflammatory activity. As shown by eq. 3, the antioxidant activity of TC was dependent on its concentration; as the concentration of TC increased, the $\mathrm{k}_{\mathrm{inh}} / \mathrm{k}_{\mathrm{p}}$ value decreased. The $\mathrm{k}_{\mathrm{inh}} / \mathrm{k}_{\mathrm{p}}$ value of $4 \mathrm{mM}$ TC was similar to that of $0.1 \mathrm{mM}$ QU or RE (Table II). Together with our previous reports, the present results indicated that in LPS-stimulated RAW264.7 cells, the approximately $50 \%$ effective dose in terms of Cox2 mRNA expression $\left(\mathrm{ED}_{50}, \mathrm{mM}\right)$ increased in the order $\mathrm{QU}$ $(0.01)>\mathrm{RE}(0.03)>\mathrm{MC}(0.4$, this work $)>\mathrm{TOC}(0.5)>>\mathrm{TC}(4$, this work, data not shown) $(14,15,31)$. The rank order of anti-inflammatory activity for the antioxidants tested may be comparable to that of their radical-scavenging activity. The anti-inflammatory activity of phenolic compounds was thought to be possibly related to their antioxidant capacity.

With regard to the VLI-mediated effects in LPS-stimulated cells, TC down-regulated the expression of Cox2 and Tnf $\alpha$ mRNAs by approximately 50\%. TC may undergo degradation upon exposure to VLI. The TC degradation products activated by VLI may suppress Cox 2 and $T n f \alpha$ mRNA expression.

We also examined the synergistic effects of TC-related compounds and polyphenols on the anti-inflammatory action. Tetracycline compounds did not promote the antiinflammatory action of polyphenols (Figure 2). However, RE had a synergistic effect with VLI on the anti-inflammatory action (Figure 5). RE is a stilbene derivative and causes a 
cis-trans isomerization reaction when exposed to light irradiation. cis-RE has been reported to have antioxidant activity and to down-regulate some inflammatory genes in mouse macrophages (32). Therefore, the synergy of the antiinflammatory effects of TC and RE upon exposure to VLI may be due to the action of cis-RE.

Our results suggested that VLI-activated TC may undergo degradation and that its degradation products may markedly enhance the expression of $\mathrm{Ho}-\mathrm{l}$. Using electron spin resonance and photometry, Chen et al. have found that ${ }^{1} \mathrm{O}_{2}$ and $\mathrm{H}_{2} \mathrm{O}_{2}$ (ROS) were generated in TC solution exposed to sunlight over the natural $\mathrm{pH}$ range, and that consequently, direct photodegradation of TC occurred (4). Several degradation products of TC have been reported, as is the case for stereoisomers of tetracycline (4-epitetracyclines), 4epioxytetracycline, etc. (33). These degradation products resulting from VLI may possibly affect inflammatory mediators. On the other hand, Ya et al. have reported that tetracyclines (TC, DC, MC) can accumulate in bacterial ribosomes, where they are photoactivated by blue light (BL) $(415 \mathrm{~nm})$ and ultraviolet light (UVA) $(365 \mathrm{~nm})$, resulting in microbial killing via $\mathrm{ROS}$ generation, and that no photobleaching of tetracyclines was observed upon exposure to either UVA or BL at $<50 \mathrm{~J} / \mathrm{cm}^{2}$ (34). Our present results indicated that MC, QU and RE were fairly photostable in RAW264.7 cells. HO-1, the inducible isoform of $\mathrm{HO}$, catalyzes the degradation of heme into biliverdin, iron, and carbon monoxide (CO), and inhibits immune responses and inflammation in vivo. Biliverdin and bilirubin are potent antioxidants that attenuate oxidative stress (35), and HO-1 has anti-inflammatory, anti-oxidant, and antiproliferative effects (36-38).

Transcription of $\mathrm{Ho}-\mathrm{l}$ is upregulated by many factors including heme, hydrogen peroxide, UV irradiation, hypoxia, and physical stress (39). On the other hand, since TC strongly induced $\mathrm{Ho}$ - $\mathrm{l}$ expression upon exposure to VLI, TC degradation products may disrupt the inhibitory activity of Kelch-like ECH-associated protein 1 (Keap1) on NRF2, which is a major EpRE/ARE activating transcription factor. This may have subsequently triggered the EpRE/ARE system, resulting in upregulation of the Ho- 1 gene $(40,41)$. TC, but not MC, was photo-activated by VLI and greatly upregulated the expression of $\mathrm{Ho}-\mathrm{I}$. It is considered that TC may induce HO-1-mediated antioxidative action upon exposure to VLI, leading to a cytoprotective action such as a strong anti-inflammatory effect (39). It has also been pointed out that a decrease in the expression and activity of Ho-l may lead to an increase in inflammation (42). Therefore, it has been suggested that induction of $\mathrm{Ho}-\mathrm{l}$ expression by VLI may offer a new anti-inflammatory function to TC in many chronic inflammatory diseases. TC as a photosensitizer may be useful for local photodynamic therapy in patients with periodontal diseases that cause alveolar bone loss.

\section{Conclusion}

LPS-induced expression of Cox $2, \operatorname{Nos} 2$ and $T n f \alpha$ in in RAW264.7 cells is suppressed by TC, MC, RE and QU. The anti-inflammatory activity declines in the order QC $>$ RE $>\mathrm{MC}>\mathrm{TC}$. These compounds are chain-breaking antioxidants and the radical-scavenging effect determined by the IP method declines in the order $\mathrm{QC}>\mathrm{RE}>\mathrm{MC}$ (estimated) $>\mathrm{TC}$. TC is a VLI-sensitive antibiotic. TC at low concentrations greatly up-regulates $\mathrm{Ho}-\mathrm{l}$ expression when activated by VLI. Further work is required to fully elucidate the underlying mechanism of the antioxidant and pro-/anti-inflammatory activities of TC.

\section{Conflicts of Interest}

The Authors have no conflicts of interest to declare regarding this study.

\section{Authors' Contributions}

S. Fujisawa conceived the present study. Y. Murakami verified the analytical methods. All Authors discussed and contributed to the final manuscript.

\section{Acknowledgements}

This work was supported by JSPS KAKENHI Grant Number JP 19K10364 from the Ministry of Education, Science, and Culture of Japan. The Authors wish to thank Shigeru Ito for the quantum chemical calculations.

\section{References}

1 Griffin MO, Ceballos G and Villarreal FJ: Anti-Inflammatory Tetracycline compounds with non-antimicrobial organ protective properties: possible mechanisms of action. Pharmacol Res 63: 102-107, 2011. PMID: 20951211. DOI: 10.1016/j.phrs.2010. 10.004

2 Chen WR and Huang $\mathrm{CH}$ : Transformation of tetracyclines mediated by $\mathrm{Mn}(\mathrm{II})$ and $\mathrm{Cu}(\mathrm{II})$ ions in the presence of oxygen. Environ Sci Technol 43: 401-407, 2009. PMID: 19238971. DOI: 10.1021/es802295r

3 Clive DLJ: Chemistry of tetracyclines. Q Rev Chem Soc 22: 435-456, 1968. DOI: 10.1039/QR9682200435

4 Chen Y, Hu C, Qu J and Yang M: Photodegradation of tetracycline and formation of reactive oxygen species in aqueous tetracycline under simulate sunlight irradiation. J Photochem Photobiol A Chem 197: 81-87, 2008. DOI: 10.1016/j.jphotochem.2007.12.007

5 Tilakaratne A and Soory M: Anti-inflammatory actions of adjunctive tetracyclines and other agents in periodontitis and associated comorbidities. Open Dent J 8: 109-124, 2014. PMID: 24976875. DOI: $10.2174 / 1874210601408010109$

6 Attur MG, Patel RN, Patel PD, Abramson SB and Amin AR: Tetracycline up-regulates COX-2 expression and prostaglandin E2 production independent of its effect on nitric oxide. J Immunol 162: 3160-3167, 1999. PMID: 10092766. 
7 Joshi N and Miller DQ: Doxycycline revisited. Arch Intern Med 157: 1421-1428, 1997. PMID: 9224219.

8 Seymour RA and Heasman PA: Tetracyclines in the management of periodontal diseases. A review. J Clin Periodontol 22: 22-35, 1995. PMID: 7706536. DOI: 10.1111/j.1600-051x.1995. tb01767.x

9 Jorgensen MG and Slots J: Practical antimicrobial periodontal therapy. Compend Contin Educ Dent 21: 111-114, 116, 118-120 2000. PMID: 11199692.

10 Kumar S, Mittal M and Khanna P: Role of antibiotics in the treatment of periodontal disease-an overview. Internet $\mathrm{J}$ Microbiol 10: 1-4, 2012. DOI: 10.5580/2af7

11 Griffin MO, Fricovsky E, Ceballos G and Villarreal F: Tetracyclines: a pleitropic family of compounds with promising therapeutic properties. Review of the literature. Am J Physiol Cell Physiol 299: C539-548, 2010. PMID: 20592239. DOI: 10.1152/ajpcell.00047.2010

12 Brito C, Stavroullakis A, Oliveira T and Prakki A: Cytotoxicity and potential anti-inflammatory activity of velutin on RAW264.7 cell line differentiation: Implications in periodontal bone loss. Arch Oral Biol 83: 348-356, 2017. PMID: 28898790. DOI: 10.1016/j.archoralbio.2017.09.001

13 Murakami Y, Ishii H, Takada N, Tanaka S, Machino M, Ito S and Fujisawa S: Comparative anti-inflammatory activities of curcumin and tetrahydrocurcumin based on the phenolic $\mathrm{O}-\mathrm{H}$ bond dissociation enthalpy, ionization potential and quantum chemical descriptor. Anticancer Res 28: 699-707, 2008. PMID: 18507010

14 Murakami Y, Kawata A, Ito S, Katayama T and Fujisawa S: The radical scavenging activity and cytotoxicity of resveratrol, orcinol and 4-allylphenol and their inhibitory effects on Cox-2 gene expression and Nf-kb activation in RAW264.7 cells stimulated with Porphyromonas gingivalis-fimbriae. In Vivo 29: 341-349, 2015. PMID: 25977379.

15 Murakami Y, Kawata A, Ito S, Katayama T and Fujisawa S: Radical-scavenging and anti-inflammatory activity of quercetin and related compounds and their combinations against RAW264.7 cells stimulated with Porphyromonas gingivalis fimbriae. Relationships between anti-inflammatory activity and quantum chemical parameters. In Vivo 29: 701-710, 2015. PMID: 26546527.

16 Kadoma Y, Ishihara M, Okada N and Fujisawa S: Free radical interaction between vitamin $\mathrm{E}$ (alpha-, beta-, gamma- and deltatocopherol), ascorbate and flavonoids. In Vivo 20: 823-827, 2006. PMID: 17203774

17 Kawata A, Murakami Y, Suzuki S and Fujisawa S: Antiinflammatory activity of $\beta$-carotene, lycopene and tri-nbutylborane, a scavenger of reactive oxygen species. In Vivo 32: 255-264, 2018. PMID: 29475907. DOI: 10.21873/in vivo.11232

18 Geoghegan F, Wong RW and Rabie AB: Inhibitory effect of quercetin on periodontal pathogens in vitro. Phytother Res 24: 817-820, 2010. PMID: 19957242. DOI: 10.1002/ptr.3014

19 Gómez-Florit M, Monjo M and Ramis JM: Quercitrin for periodontal regeneration: effects on human gingival fibroblasts and mesenchymal stem cells. Sci Rep 5: 16593, 2015. PMID: 26558438. DOI: 10.1038/srep16593

20 Napimoga MH, Clemente-Napimoga JT, Macedo CG, Freitas FF, Stipp RN, Pinho-Ribeiro FA, Casagrande R and Verri WA Jr: Quercetin inhibits inflammatory bone resorption in a mouse periodontitis model. J Nat Prod 76: 2316-2321, 2013. PMID: 24246038. DOI: $10.1021 / \mathrm{np} 400691 \mathrm{n}$
21 Murakami Y, Kawata A, Seki Y, Koh T, Yuhara K, Maruyama T, Machino M, Ito S, Kadoma Y and Fujisawa S: Comparative inhibitory effects of magnolol, honokiol, eugenol and biseugenol on cyclooxygenase-2 expression and nuclear factorkappa B activation in RAW264.7 macrophage-like cells stimulated with fimbriae of Porphyromonas gingivalis. In Vivo 26: 941-950, 2012. PMID: 23160676.

22 Fujisawa $S$, Ishihara $M$ and Kadoma $Y$ : Kinetics of the radical scavenging activity of beta-carotene-related compounds. SAR QSAR Environ Res 15: 33-41, 2004. PMID: 15113067. DOI: 10.1080/1062936032000169651

23 Kadoma Y and Fujisawa S: Radical-scavenging activity of dietary phytophenols in combination with co-antioxidants using the induction period method. Molecules 16: 10457-10470, 2011. PMID: 22173338. DOI: 10.3390/molecules161210457

24 Zingg JM and Azzi A: Non-antioxidant activities of vitamin E. Curr Med Chem 11: 1113-1133, 2004. PMID: 15134510. DOI: 10.2174/0929867043365332

25 Lobo V, Patil A, Phatak A and Chandra N: Free radicals, antioxidants and functional foods: Impact on human health. Pharmacogn Rev 4: 118-126, 2010. PMID: 22228951. DOI: 10.4103/0973-7847.70902

26 Kraus RL, Pasieczny R, Lariosa-Willingham K, Turner MS, Jiang A and Trauger JW: Antioxidant properties of minocycline: neuroprotection in an oxidative stress assay and direct radicalscavenging activity. J Neurochem 94: 819-827, 2005. PMID: 16033424. DOI: $10.1111 / \mathrm{j} .1471-4159.2005 .03219 . x$

27 Burton GWand Ingold KU: beta-Carotene: an unusual type of lipid antioxidant. Science 224: 569-573, 1984. PMID: 6710156. DOI: $10.1126 /$ science. 6710156

28 Kessler M, Höper J, Harrison DK, Skolasinska K, Klövekorn WP, Sebening F, Volkholz HJ, Beier I, Kernbach C, Rettig V and Richter $\mathrm{H}$ : Tissue $\mathrm{O}_{2}$ supply under normal and pathological conditions. In: Oxygen Transport to Tissue-V. Advances in Experimental Medicine and Biology. Lübbers DW, Acker H, Leniger-Follert E and Goldstrick TK (eds.). Springer, Boston, MA, USA, vol 169, pp. 69-80, 1984.

29 Pryor WA: Why is the hydroxyl radical the only radical that commonly adds to DNA? Hypothesis: it has a rare combination of high electrophilicity, high thermochemical reactivity, and a mode of production that can occur near DNA. Free Radic Biol Med 4: 219-223, 1988. PMID: 2834274. DOI: 10.1016/08915849(88)90043-3

30 Kondo Y, Ohnishi M and Kawaguchi M: Detection of lipid peroxidation catalyzed by chelated iron and measurement of antioxidantactivity in wine by a chemiluminescence analyzer. J Agric Food Chem 47: 1781-1785, 1999. PMID: 10552452. DOI: $10.1021 / \mathrm{j} f 9811119$

31 Murakami Y, Kawata A, Koh T, Seki Y, Tamura S, Katayama T and Fujisawa S: Inhibitory effects of tocopherols on expression of the cyclooxygenase- 2 gene in RAW264.7 cells stimulated by lipopolysaccharide, tumor necrosis factor- $\alpha$ or Porphyromonas gingivalis fimbriae. In Vivo 27: 451-458, 2013. PMID: 23812214.

32 Leiro J, Alvarez E, Arranz JA, Laguna R, Uriarte E and Orallo F: Effects of cis-resveratrol on inflammatory murine macrophages: antioxidant activity and down-regulation of inflammatory genes. J Leukoc Biol 75: 1156-1165, 2004. PMID: 14982945. DOI: $10.1189 /$ jlb.1103561

$33 \mathrm{Wu}$ X, Wei Y, Zheng J, Zhao X and Zhong W: The behavior of tetracyclines and their degradation products during swine 
manure composting. Bioresour Technol 102: 5924-5931, 2011 PMID: 21444199. DOI: 10.1016/j.biortech.2011.03.007

$34 \mathrm{He}$ Y, Huang YY, Xi L, Gelfand JA and Hamblin MR: Tetracyclines function as dual-action light-activated antibiotics. PLoS One 13: e0196485, 2018. PMID: 29742128. DOI: 10.1371/journal.pone.0196485

35 Agarwal A and Bolisetty S: Adaptive responses to tissue injury: role of heme oxygenase-1. Trans Am Clin Climatol Assoc 124: 111-122, 2013. PMID: 23874015.

36 Lai ZR, Ho YL, Huang SC, Huang TH, Lai SC, Tsai JC, Wang CY, Huang GJ and Chang YS. Antioxidant, anti-inflammatory and antiproliferative activities of Kalanchoe gracilis (L.) DC stem. Am J Chin Med 39: 1275-1290, 2011. PMID: 22083996. DOI: 10.1142/S0192415X1100955X

37 Yamada N, Yamaya M, Okinaga S, Nakayama K, Sekizawa K, Shibahara S and Sasaki H: Microsatellite polymorphism in the heme oxygenase-1 gene promoter is associated with susceptibility to emphysema. Am J Hum Genet 66: 187-195, 2000. PMID: 10631150. DOI: 10.1086/302729

38 Gabunia K, Ellison SP, Singh H, Datta P, Kelemen SE, Rizzo V and Autieri MV: Interleukin-19 (IL-19) induces heme oxygenase1 (HO-1) expression and decreases reactive oxygen species in human vascular smooth muscle cells. J Biol Chem 287: 2477 2484, 2012. PMID: 22158875. DOI: 10.1074/jbc.M111.312470
39 Morse D and Choi AM: Heme oxygenase-1: the "emerging molecule" has arrived. Am J Respir Cell Mol Biol 27: 8-16, 2002. PMID: 12091240. DOI: 10.1165/ajrcmb.27.1.4862

40 Itoh K, Mimura J and Yamamoto M: Discovery of the negative regulator of Nrf2, Keap1: a historical overview. Antioxid Redox Signal 13: 1665-1678, 2010. PMID: 20446768. DOI: 10.1089/ars.2010.3222

41 Sun J, Brand M, Zenke Y, Tashiro S, Groudine M and Igarashi $\mathrm{K}$ : Heme regulates the dynamic exchange of Bach1 and NF-E2related factors in the Maf transcription factor network. Proc Natl Acad Sci USA 101: 1461-1466, 2004. PMID: 14747657. DOI: 10.1073/pnas.0308083100

42 Poss KD and Tonegawa S: Reduced stress defense in heme oxygenase 1-deficient cells. Proc Natl Acad Sci USA 94: 10925-10930, 1997. PMID: 9380736. DOI: 10.1073/pnas. 94.20.10925
Received September 30, 2019

Revised October 17, 2019

Accepted October 21, 2019 